\title{
Spatial and temporal trends of precipitation and temperature for the MPUAT service area, Rajasthan, India
}

\author{
Shreepada Devi*, R. C. Purohit**, S. R. Bhakar**, S. S. Lakhawat*** \\ *M. Tech Scholar, Department of Soil and Water Engineering, CTAE, MPUAT, Udaipur \\ **Professor, Department of Soil and Water Engineering, CTAE, MPUAT, Udaipur \\ ***Asst. Prof., Department of Horticulture, Rajasthan College of Agriculture, Udaipur
}

\begin{abstract}
The present study focuses on the long term trends of meteorological parameters like precipitation and temperature of the MPUAT service area, Rajasthan, India which is mainly located in humid and sub-humid region. Trend analysis of the seasonal (pre-monsoon, monsoon, post-monsoon and winter) and annual daily rainfall and temperature at the spatial and temporal scales was carried out for 7 stations of the MPUAT, service area. Statistical trend analysis technique, namely the Mann-Kendall test, was used to examine trends (19842014) at the 5\% level of significance. Both positive and negative trends were observed in both seasonal and annual events of rainfall and temperature.The spatial variations of the trends in seasonal (pre-monsoon, monsoon, post-monsoon and winter) and annual daily rainfall and temperature were also determined using the inverse-distance-weighted (IDW) interpolation technique. IDW results are helpful to identify trends and variability in seasonal and annual rainfall and temperature in space and time for the study locations where the data is not available and the quality of data is not good. These spatial maps of temperature and rainfall can aid in designing the effective water resources planning over the MPUAT service area under climate change.
\end{abstract}

\section{Introduction}

Climate change is becoming the hottest topic to the entire globe. Climate may change in different ways, over different time scales and at different geographical scales (Parekh and Prajapati, 2015).Environment and societies have always been vulnerable to extreme weather and drastic shift in the distribution of weather patterns. But over the last few decades, evidence is intensifying that distribution of weather patterns are vulnerable to anthropogenic factors as well.In another sense, climate change means the shifting of climatic or meteorological parameters viz. precipitation, maximum temperature, minimum temperature, solar radiation, relative humidity, wind speed etc. and many other factors where as global warming or cooling which refer the changes of the surface temperature (Back and Bretherton 2005).Globally climate change has caught increasing attention in research field due to its direct and indirect impacts on all major sectors, such as hydrometeorological, ecological, biological and socio-economic sectors (IPCC, 2001, 2007 and 2013). Climate change is a long term process. It has raised as most alarming issue for the whole world. Therefore, quantification of climatic changes has become necessary. Trend analysis is a method to determine the spatial variation and temporal changes for different parameters associated to climate (Swain, et al. 2015). Mann-Kendall (MK) is one of the most commonly used non-parametric tests for detecting climatic changes in time series and trend analysis (Mann 1945; Kendall 1955). MK trend test is a rank correlation test for two groups of observations proposed by Kendall (1955). Mann-Kendall (MK) test is able to suggest the significant trend in hydrological and climatological time-series data (Modarres and Silva, 2007).

For the Indian context there are several works regarding MK test. Jhajharia et al. (2009) showed the analyses of temporal characteristics of pan evaporation using Mann-Kendall test. Burn et al. (2011) did their study on climate change on a local basis and the hydrological trend in total annual precipitation rate on the basis of Mann Kendall (MK) test analysis coupled with the wavelet transformation. Mondal et al. (2012) studied the changing pattern of long term trend of rainfall in Orissa coastal region, India. Patle et al. (2013) did their study on temporal variability in climatic parameters and potential evapotranspiration with the reference of crop from 1981 to 2011. Duhan et al. (2013) studied the spatial and temporal variability in the air temperatures at Madhya Pradesh of India based on monthly, annual and seasonal range from 1901 to 2002 using MK test. They also studied on seasonal and annual trends of rainfall for the Haryana and Madhya Pradesh, India (Duhan and Pandey2013). Jain et al. (2013) did an analysis of rainfall and temperature trends using MK test for northeast India. Sonali and Kumar (2013) studied a spatio-temporal trend analysis using MK test with annual maximum and minimum temperatures of India. Trend analysis namely the Mann-Kendall test and Sen's slope estimator of the mean and extreme annual daily rainfall and temperature at the spatio-temporal level was done for all the 33 urban areas of Rajasthan state of India (Pingale et al. 2014). Suryavanshi et al. (2014) studied the trend analysis of historic past climatic variables using MK test for the Betwa river basin in India. Chaudhuri and Dutta (2014) described a trend of pollutants, temperature and humidity over Kolkata region of India using MK test and 
different ARIMA models. Bisai et al. (2014) used Mann-Kendall test for detection of surface air temperature for weather observation in Kolkata, India. The long term trends of meteorological parameters like precipitation, temperature, solar radiation, wind direction etc. of Western Rajasthan using geographical information system and statistical techniques (Kundu et al. 2015). Roy (2015) detected increasing trends in temperature and decreasing trends in rainfall over Rajasthan during last century and also delay in onset of monsoon resulting increase in post monsoon rainfall. The decreasing annual and monsoon rainfall of India in most of the subdivisions, and temperature fluctuations were observed in all the places (Mondal et al., 2015). Shrestha et al., (2016) observed trends and changes in daily temperature and precipitation extremes over the Koshi river basin (1975-2010) and the results indicate that the risk of extreme climate events over the basin is increasing, which will increase people's vulnerability and has strong policy implications.

\section{Study area}

\section{Materials And Method}

The current study is carried out over the Maharana Pratap University of Agriculture and Technology (MPUAT) service area Udaipur, Rajasthan, India. MPUAT service area consists of seven districts lying in the south and south-eastern part of Rajasthan. Rajasthan is the largest state with latitude $27.0238^{\circ} \mathrm{N}$, and longitude $74.2179^{\circ} \mathrm{E}$ of India constituting 10.4 per cent of total geographical area and 5.67 per cent of total population of India. It consists of ten agro-climatic zones from which the entire MPUAT service area falls under two agroclimatic zones i.e. sub-humid southern plains \& Aravalli hills and humid southern plain. The soil of sub-humid southern plain are lithosols at foot hills and alluvial in plains while humid plain has Predominantly reddish medium texture, well drained calcareous, shallow on hills, deep soil in valleys .Udaipur, Bhilwara, Chittorgarh, Rajsamand districts comes under sub-humid \& Aravalli hills and humid southern plain consists of Banswara, Dungarpur, Pratapgarh districts (http://waterresources.rajasthan.gov.in). Over the entire MPUAT service area, the types of climate are also different from one district to another. Udaipur and Banswara districts experiences tropical climate which have a non-arid climate in which twelve months have mean temperature of at least $18^{\circ} \mathrm{C}$ and average precipitation of at least $60 \mathrm{~mm}$. The climate of Bhilwara and Dungarpur districts have a local steepe climate which is a semi-arid climate having average July temperature ranges from 21 to $23^{\circ} \mathrm{C}$ and in winter it ranges from -13 and $0^{\circ} \mathrm{C}$ and an average temperature of $460 \mathrm{~mm}$ in north and $260 \mathrm{~mm}$ in south. Pratapgarh experiences a temperate climate, it is a subtropical climate with temperature is moderate not so cold and hot where the climate of Chittorgarh district has a dry climate which is a arid climate having average temperature is below $18^{\circ} \mathrm{C}$ and average precipitation is less than $250 \mathrm{~mm}$ throughout the year. MPUAT service area accounts for $22.9 \%$ geographical area of the state. There is a sizeable area of 10.58 lac hectare under barren and uncultivable land. About 5.61 lac hectare area is under pasture and grazing land. The size of culturable wasteland is 7.29 lac hectares.

\section{Data used}

Monthly precipitation and mean temperature data of seven districts over the period of 30 years (19842014) has been downloaded from India water portal site (http://www.indiawaterportal.org). In the present study spatial and temporal variability of both parameters (precipitation and temperature) has been studied at annual and seasonal basis (pre-monsoon, monsoon, post-monsoon and winter) for detailed analysis. Methodology of dividing data into seasonal basis helps in eliminating the effect of seasonality in the time series. For the development of GIS based maps the shape file of MPUAT service area has been collected from NBSS, regional centre, Udaipur, Rajasthan, India.

\section{Mann-Kendell test}

In the present study a popular non- parametric method Mann-Kendall test has been used to detect trend in the rainfall and temperature at 5\% significance level. Because of non-parametric methods are more suitable to detection of trend rather than the parametric methods in hydro-metrological data (Helselet al. 2002; Hirsch, 1982). Mann-Kendall test is rank based test, used where autocorrelation is not significant and it can tolerate to outliers, distribution free and has higher power than the other test (Duhan and Pandey, 2013). Therefore in the present study Mann-Kendall test is applied after pre-whitening for all meteorological parameters at premonsoon, monsoon, post- monsoon to eliminate the effect of autocorrelation in the data series (Von Storch, 1995; Partal and Kahya, 2006; Mohammad and Jha, 2014). The standardized Mann-Kendall test $Z$ value for computation of statistical significance of trend in the time series is given as follow: 


$$
Z=\left\{\begin{array}{lc}
\frac{S-1}{\sqrt{\operatorname{Var}(S)}} & \text { if } S>0 \\
0 & \text { if } S=0 \\
\frac{S+1}{\sqrt{\operatorname{Var}(S)}} & \text { if } S<0
\end{array}\right.
$$

Where $\mathrm{S}$ is the statistic value, which possesses normal distribution for large number of sample size (Kendall, 1975) and can be computed as;

$$
\mathrm{S}=\sum_{\mathrm{k}=1}^{\mathrm{n}-1} \operatorname{Sgn}\left(\mathrm{x}_{\mathrm{j}}-\mathrm{x}_{\mathrm{i}}\right)
$$

Where,

$\mathrm{xi}$ is ranked from $\mathrm{i}=1,2,3 \ldots \mathrm{n}-1$

$\mathrm{xj}$ is ranked from $\mathrm{j}=\mathrm{i}+1,2,3 \ldots \mathrm{n}$ in the time series.

The values of $+Z$ and $-Z$ indicates upward and downward trend respectively. The $Z$ values of Mann-Kendall test accept the null hypotheses of no trend when $\pm Z \leq Z 1-x / 2$, where $x$ is the level of significance at two tailed trend test. In the present study test will be carried out at $5 \%$ significance level, therefore when $Z$ value exceeds \pm 1.96 null hypotheses is rejected and show the existence of trend in the series.

\section{Inverse Distance Weighting Method (IDW)}

It is a type of deterministic method for multivariate interpolation with a known scattered set of points. The assigned values to unknown points are calculated with a weighted average of the values available at the known points. Distance Weighting (IDW) is based on the assumption that the nearby values contribute more to the interpolated values than distant observations. In other words, for this method, influence of a known data point is inversely related to the distance from the unknown location that is being estimated. The advantage of IDW is that it is intuitive and efficient. This interpolation works best with evenly distributed points.

\section{Trends in precipitation}

\section{Results And Discussion}

Spatial distribution of annual mean, pre-monsoon ( April, May and June), monsoon (Jul to September), post-monsoon (October and November) and winter season (December, January and February) of precipitation for the 7 districts of MPUAT service area are plotted in GIS based maps by using IDW method.

Table 1 Mann Kendell Z value for Rainfall for the period 1984-2014

\begin{tabular}{|c|c|c|c|c|c|c|}
\hline \multirow{2}{*}{ S. No. } & Name of the & \multicolumn{5}{|c|}{ Man Kendell Z value for rainfall for 1984-2014 } \\
\cline { 3 - 7 } & District & AM & PRMN & MN & POMN & WN \\
\hline 1 & Udaipur & 2.24 & 0.49 & 2.02 & 0.97 & -0.13 \\
\hline 2 & Bhilwara & 0.68 & 0.49 & 0.37 & -0.23 & 0.55 \\
\hline 3 & Chittorgarh & 1.46 & 0.36 & 1.53 & -0.58 & 0.02 \\
\hline 4 & Rajsamand & 2.12 & -0.09 & 1.48 & 1.5 & -0.84 \\
\hline 5 & Banswara & -0.17 & -0.39 & -0.12 & -0.52 & 0.49 \\
\hline 6 & Dungarpur & 1.67 & 0.05 & 1.67 & -0.14 & 1.1 \\
\hline 7 & Pratapgarh & 1.87 & 0.39 & 1.77 & -0.48 & 0.12 \\
\hline
\end{tabular}

Note: $-1.96<Z<1.96=$ No trend, $Z>1.96=$ Increase in trend, $Z<-1.96=$ Decrease in trend

AM - Annual mean, PRMN - Pre-monsoon, MN - Monsoon, POMN - Post-monsoon, WN - Winter.

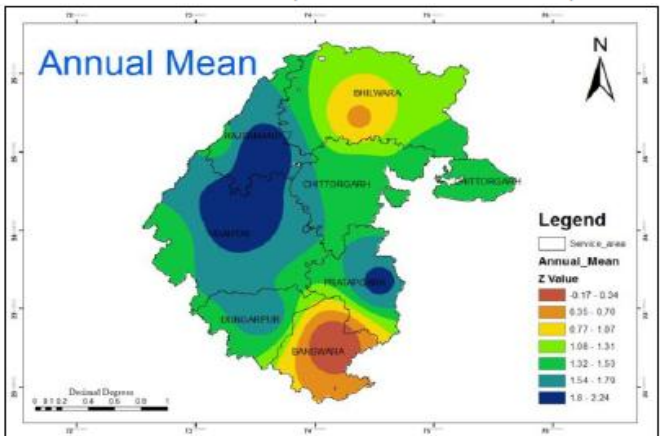

Fig 1.1: Mann-Kendell $Z$ value for annual mean precipitation

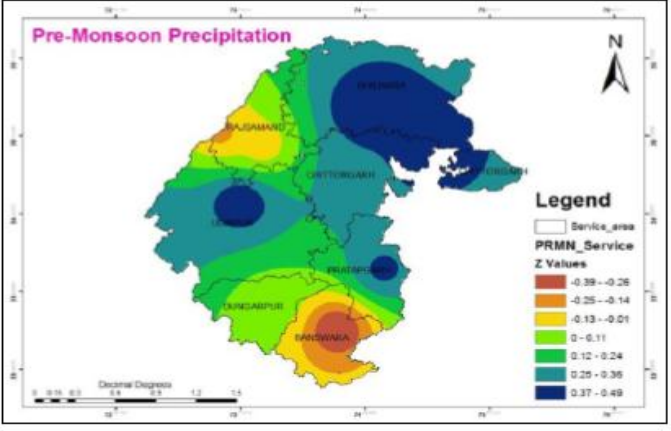

Fig 1.2: Mann-Kendell $Z$ value for pre-Monsoon precipitation 


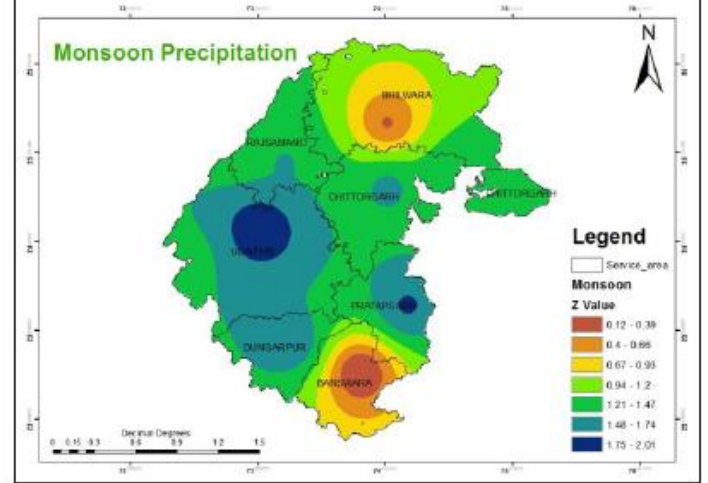

Fig 1.3: Mann-Kendell $Z$ value for Monsoon precipitation

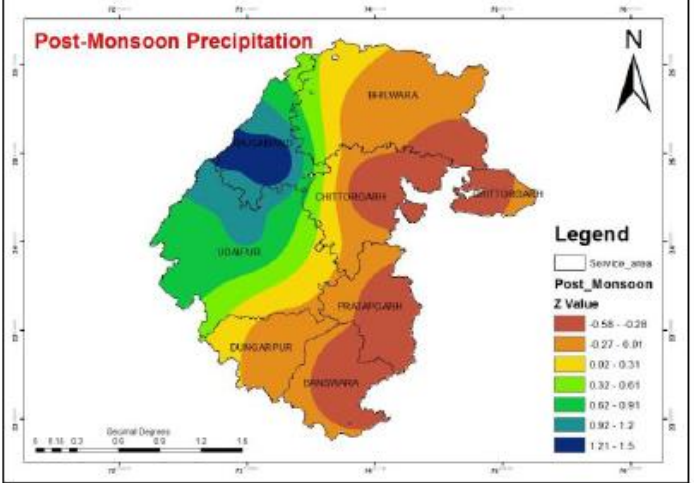

Fig 1.4: Mann-Kendell $Z$ value for postMonsoon precipitation

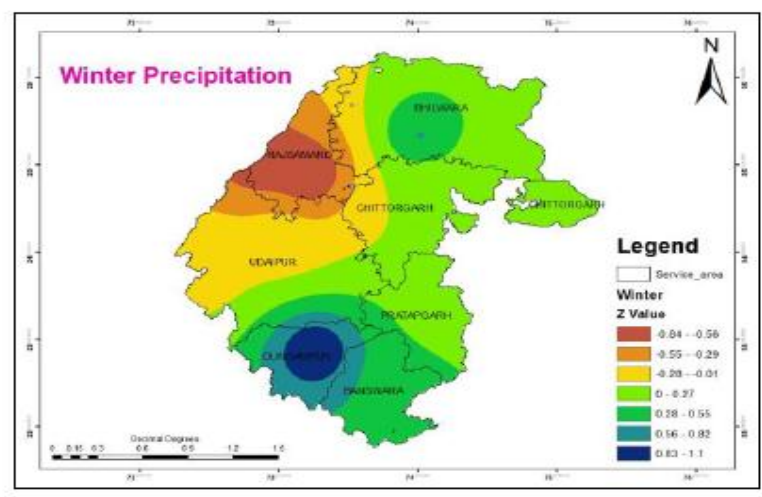

Fig 1.5: Mann-Kendell $Z$ value for winter precipitation

\section{Trends in temperature}

Like precipitation the trend of temperature is also calculated by using the non parametric Mann Kendell test for Annual mean, pre-monsoon, monsoon, post-monsoon and winter. The average temperature is used for the calculation. The calculated trend has been plotted in GIS based maps by using IDW method.

Table 2 Mann-Kendell Z value for temperature from 1984-2014

\begin{tabular}{|c|c|c|c|c|c|c|}
\hline \multirow{2}{*}{ Sr. No } & \multirow{2}{*}{$\begin{array}{c}\text { Name of the } \\
\text { district }\end{array}$} & \multicolumn{4}{|c|}{ Mann Kendell Z value for temperature for 1984-2014 } \\
\cline { 3 - 7 } & AM & PRMN & MN & POMN & WN \\
\hline 1 & Udaipur & 2.14 & 2.24 & 1.14 & 1.09 & 2.07 \\
\hline 2 & Bhilwara & 2.92 & 1.26 & 1.43 & 1.87 & 2.65 \\
\hline 3 & Chittorgarh & 3.03 & 1.7 & 1.7 & 1.5 & 2.31 \\
\hline 4 & Rajsamand & 2.11 & 1.29 & 0.88 & 1.19 & 2.38 \\
\hline 5 & Banswara & 2.55 & 1.67 & 1.09 & 1.36 & 2.38 \\
\hline 6 & Dungarpur & 2.18 & 1.56 & 0.85 & 1.16 & 2.14 \\
\hline 7 & Pratapgarh & 2.12 & 2.2 & 1.11 & 1.01 & 2.02 \\
\hline
\end{tabular}

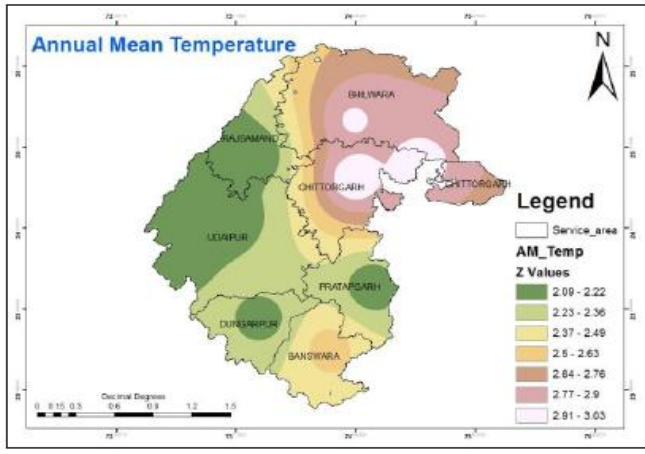

Fig 2.1: Mann-Kendell $Z$ value for annual mean temperature

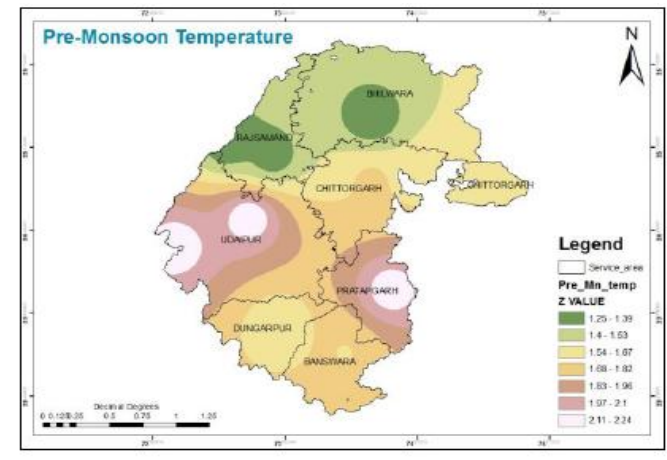

Fig 2.2: Mann-Kendell $Z$ value for pre-Monsoon temperature 


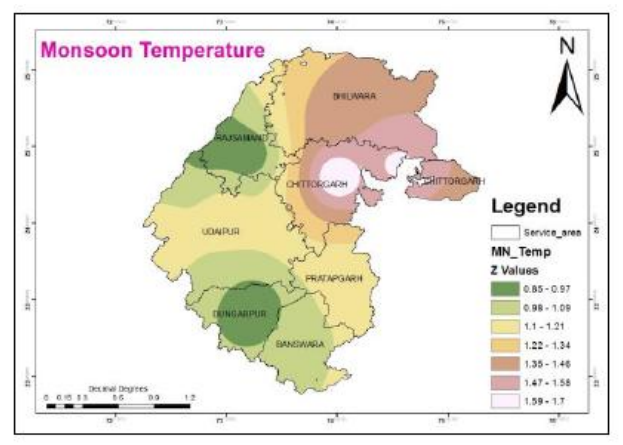

Fig 2.3: Mann-Kendell $\mathrm{Z}$ value for Monsoon temperature

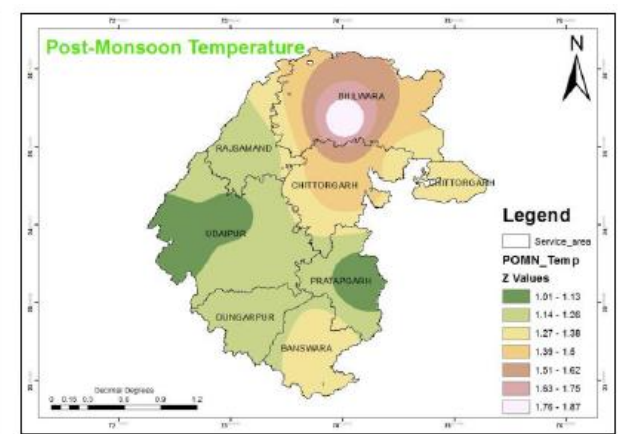

Fig 2.4: Mann-Kendell $Z$ value for postMonsoon temperature

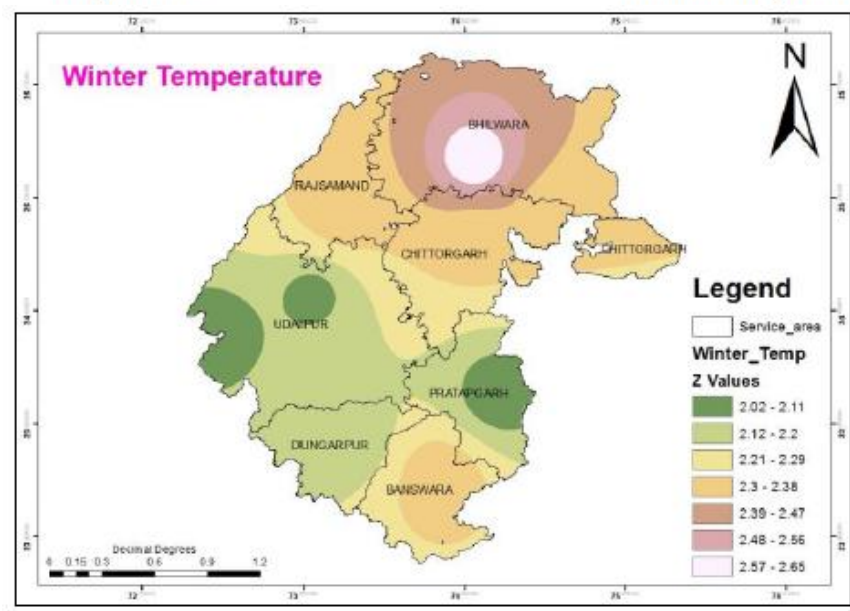

Fig 2.5: Mann-Kendell $Z$ value for winer temperature

\section{Conclusion}

The present study is carried out to examine the spatial and temporal variability and trends in precipitation and mean temperature at annual and seasonal basis for seven districts of MPUAT service area, Rajasthan, India.The mean annual rainfall has an increasing trend for the Udaipur and Rajsamand districts where there is no trend for other districts. For seasonal basis there is a no trend for pre-monsoon season for all the seven districts under the study region. Only Udaipur district showed a higher trend for monsoon season and other districts has no trend for the same period. For post-monsoon and winter seasons there is always no trend for all the seven districts under the study area. There is a higher trend in temperature at $5 \%$ significance level for annual temperature at all 7 districts of the study area in the period of 1984-2014. The decrease in trend is found in the pre-monsoon, monsoon and post-monsoon seasons on seasonal basis. The increase in trend for annual mean temperature increases with latitude and also increases with decrease in vegetation density in the study area.

\section{References}

[1] Back, L. E. and C. S. Bretherton. 2005. The relationship between wind speed and precipitation in the pacific ITCZ. Journal of Climate, Vol. 18, pp 4317-4328.

[2] Bisai, D., Chatterjee, S., Khan, A. and N. K. Barman. 2014. Application of sequential Mann-Kendall test for detection of approximate significant change point in surface air temperature for Kolkata weather observatory, West Bengal, India. International Journal of Current Research,Vol. 6,pp. 5319-5324.

[3] Burn, D.H., Mansour, R., Zhang, K. and P. H. Whitfield. 2011. Trends and variability in extreme rainfall events in British Columbia. Canadian Water Resources Journal, 36(1), pp.67-82.

[4] Chaudhuri, S. and D. Dutta. 2014. Mann-Kendall trend of pollutants, temperature and humidity over an urban station of India with forecast verification using different ARIMA models. Environmental Monitoring and Assessment, Vol. 186,pp. 4719-4742.

[5] Duhan, D. and A. Pandey. 2013. Statistical analysis of long term spatial and temporal trends of precipitation during 1901-2002 at Madhya Pradesh, India. Atmospheric Research, Vol. 122, pp. 136-149.

[6] Duhan, D. and A. Pandey. 2013. Long-term Trends in Rainfall Pattern over Haryana, India.Journal of Environment and Earth Science, Vol.5(5), pp. 283-292.

[7] Duhan, D., Pandey, A., Gahalaut K. P. S. and R. P. Pandey. 2013. Spatial and temporal variability in maximum, minimum and mean air temperatures at Madhya Pradesh in central India. ComptesRendus Geoscience,Vol. 345, pp. 3-21.

[8] Helsel, D.R., and R. M. Hirsch. 2002. Statistical methods in water resources techniques of water resources investigations. Book 4 (Chapter A3),U.S. Geological Survey(522 pages). 
[9] Hirsch, R.M., Slack, J.R., and R. A. Smith. 1982. Techniques of trend analysis for monthly water quality data. Water Resour. Res.Vol. 18 (1), pp. 107-121.

[10] IPCC. 2001. Contribution of Working Group I to the Third Assessment Report of the Intergovernmental Panel on Climate Change. Cambridge University Press, Cambridge, UK.

[11] IPCC. 2007. Contribution of Working Group I to the Fourth Assessment Report of the Intergovernmental Panel on Climate Change. Cambridge University Press, Cambridge, UK.

[12] IPCC. 2013. Contribution of Working Group I to the IPCC Fifth Assessment Report Climate Change. The physical science basis

[13] Jain, S. K., Kumar, V. and M. Saharia. 2013. Analysis of rainfall and temperature trends in northeast India. International Journal of Climatology, Vol. 33, pp. 968-978.

[14] Jhajharia, D., Shrivastava, S. K., Sarkar, D. and S. Sarkar. 2009. Temporal characteristics of pan evaporation trends under the humid conditions of North east India. Agricultural and Forest Meteorology. 149(5), pp. 763-770

[15] Kendall, M. G. (1955). Rank Correlation Methods. Griffin, London.

[16] Kundu, A., Chatterjee, S., Dutta, D. and A. R. Siddiqui. 2015. Meteorological Trend Analysis in Western Rajasthan (India) using Geographical Information System and Statistical Techniques. Jour. of Environ. Earth Sci., Vol 5(5), pp 90-99.

[17] Mann, H. B. (1945). Nonparametric tests against trend. Econometrica,Vol. 13, pp. 245-259.

[18] Modarres, R. and V. Silva. 2007. Rainfall trends in arid \& semi-arid regions of Iran. Journal of Arid Environments, Vol. 70, pp. 344-355.

[19] Mohammad, S. and M. K. Jha, 2014. Seasonal and annual precipitation time series trend analysis in North Carolina, United States. Atmospheric ResearchVol. 137, pp. 183-194.

[20] Mondal, A., Khare, D. and S. Kundu. 2015. Spatial and temporal analysis of rainfall and temperature trend of India. Theoretical and Applied Climatology, Vol. 122(1-2), pp.143-158.

[21] Mondal, A., Kundu, S. and A. Mukhopadhyay. 2012. Rainfall trend analysis by Mann-Kendall test: A case study of north-eastern part of Cuttack district, Orissa. International Journal of Geology, Earth and Environmental Sciences, Vol. 2, pp. 70-78.

[22] Parek, F. and K. P. Prajapati. 2015. Climate change impacts on crop water requirement for Sukhireservoir project. Internat. Jour. of Innovative Res. in Sci. Engg. and Tech., Vol. 2(9), pp.4685-4692.

[23] Partal, T., \&E. Kahya. 2006. Trend analysis in Turkish precipitation data. Hydrological Processes, Vol. 20, pp. $2011-2026$.

[24] Patle, G. T., Singh, D. K., Sarangi, A., Rai, A., Khanna, M. and R. N. Sahoo. 2013. Temporal variability of climatic parameters and potential evapotranspiration. The Indian Journal of Agricultural Sciences, Vol. 83, pp. 518-524.

[25] Pingale, S. M., Khare, D., Jat, M. K. and J. Adamowski. 2014. Spatial and temporal trends of mean and extreme rainfall and temperature for the 33 urban centers of the arid and semi-arid state of Rajasthan, India. Atmospheric Research,Vol. 138, pp. 73-90.

[26] Roy, A. D. 2015. Trend detection in Temperature and Rainfall over Rajasthan during the Last Century. Asian Journal of Research in Social Sciences and Humanities. Vol., 5(2), pp. 12-26.

[27] Shrestha, A. B., Bajracharya, S. R., Sharma, A. R., Duo, C. and A. Kulkarni. 2016. Observed trends and changes in daily temperature and precipitation extremes over the Kosi river basin 1975-2010. Internat. Jour. of climat.Vol. 5, pp. 269-275.

[28] Sonali, P. and D. N. Kumar. 2013. Review of trend detection methods and their application to detect extreme temperature changes in India. Journal of Hydrology, Vol. 476, pp. 212-227.

[29] Suryavanshi, S., Pandey, A., Chaube, U. C. and N. Joshi. 2014. Long-term historic changes in climatic variables of Betwa Basin, India. Theoritical and Applied Climatology, Vol. 117, pp. 403-418.

[30] Swain, S., Verma, M., and M. K. Verma. 2015. Statistical trend analysis of monthly rainfall for Raipur district, Chhattisgarh. Int. J. Adv. Engg. Res. Studies/IV/II/Jan.-March, pp. 87-89.

[31] Von Storch, H. 1995. Misuses of statistical analysis in climate research. In: Storch, H.V., Navarra, A. (Eds.), Analysis of Climate Variability: Applications of Statistical Techniques. Springer, pp. 11-26 